\author{
Dariusz Filip \\ https://orcid.org/0000-0002-6905-1004 \\ Department of Finance \\ Faculty of Social and Economic Sciences \\ Cardinal Stefan Wyszynski University \\ in Warsaw (UKSW), Poland \\ d.filip@uksw.edu.pl
}

\title{
Manager's gender and professional credentials in the performance of Polish investment funds
}

Accepted by Editor Ewa Ziemba | Received: December 4, 2018 | Revised: May 29, 2019 | Accepted: July 2, 2019.

\begin{abstract}
Aim/purpose - This paper focuses on establishing whether investment fund performance is related to managerial characteristics, such as a manager's gender and professional credentials.

Design/methodology/approach - The investigation was conducted on a relatively large study sample covering 275 managers of 98 domestic equity funds operating in Poland in the period 2000-2017. The verification of the hypotheses was based on three groups of research tools, including tests for differences in the mean values and distributions of rates of return in two samples of funds, where a gender and Chartered Financial Analyst (CFA) were grouping variables, and regression models, where a gender or CFA were dummy factors implemented into asset pricing models.

Findings - The obtained results show that there are no disproportions in the performance achieved by funds managed by men and funds (co-)managed by women or managers with or without CFAs. However, the findings related to the latter variable are ambiguous, in particular when regression methods are employed or basic measures of return are used.

Research implications/limitations - In order to clarify the influence of some managerial characteristics on fund performance further research in this field is needed. Nevertheless, the results may be of interest to both individual investors and fund families.

Originality/value/contribution - To our knowledge, it is the first paper to evaluate the performance of Polish investment funds in relation to managerial characteristics. Moreover, what contributes to the originality of the research is the application of a relatively extensive set of measures of return and the use of a proprietary database with unique variables describing a fund manager's profile.
\end{abstract}

Cite as: Filip, D. (2019). Manager's gender and professional credentials in the performance of Polish investment funds. Journal of Economics \& Management, 38(4), 46-66. https://doi.org/ $10.22367 /$ jem.2019.38.03 
Keywords: mutual funds, performance, managerial characteristics, portfolio managers. JEL Classification: G23, J24, M12.

\section{Introduction}

Socio-demographic issues might be an important factor influencing the decisions made by managers of economic entities, which in turn determine their future management effects. There is an assumption on financial markets providing that if a market is effective, no investor, regardless of his or her characteristics or skills, will provide superior performance using investment strategies based on public information. Nonetheless, there are two theories referring to the resource-based view, i.e. the Human Capital Theory and the Social Capital Theory, which state that well-educated fund managers with good social skills display better managerial and networking skills, which could lead to better performance (cf. Felício, Couto, \& Caiado, 2014; Pasban \& Nojedeh, 2016).

Social skills are underlain by certain socio-demographic manager attributes, one of them is a gender. It is believed that a woman's presence in a team may cause slightly different reactions of male team members. The inclusion of femininity in the performance of portfolio management teams seems an interesting issue, in particular if the profession of a portfolio manager is dominated by men. As shown in the study by Filip (2018b), women managing funds in Poland constitute just under $4 \%$ of the total number of fund managers, which is considerably below the level recorded on more developed markets, where the share of women is more than $10 \%$ (cf. Niessen-Ruenzi \& Ruenzi, 2013).

In the area of human capital, in turn, the focus should be placed on competencies of the management staff. Portfolio managers, apart from having a university degree and holding relevant licences, aspire to improving their qualifications by obtaining various certifications of specialised knowledge and skills. In Polish circumstances, the stock broker licence or the investment advisor licence is widespread in the discussed sector. Holding a Chartered Financial Analyst (CFA) or another certificate (e.g. the Critical Path Method - CPM, the Certified International Investment Analyst - CIIA) can be, however, a distinctive feature for a fund manager. With reference to the findings of the above-mentioned study (Filip, 2018b), ca. 25\% of Polish managers hold the CFA certificate and nearly $2.5 \%$ - CIIA certificate.

This paper focuses on determining whether investment fund performance is related to managerial characteristics, such as a manager's gender and professional credentials. In this respect, it seems relevant to present the differences in returns of male-managed funds and funds cooperating with female managers as well as in returns of funds managed by managers with or without CFAs. 
The results may be of interest to both individual investors and fund families. For the former addressees of the paper, the findings of the study could serve as assistance in choosing the funds whose managers may be predisposed to achieve better results. For the latter group of recipients, the relationship between performance and socio-demographic aspects might be important with regard to the applied recruitment procedures that support employing managers who demonstrate the desirable characteristics.

The remaining part of this paper is organised as follows. The next section reviews the existing literature and presents the formulated hypotheses on the issue discussed in this paper. The third chapter provides a description of the data and methodology. The empirical results are reported in the fourth section, which is followed by the conclusions of the study.

\section{Literature review and hypotheses}

The performance of active mutual funds has continually been a research focus for both investors and financial economists. Starting from Jensen (1968), who evidenced negative fee and trading cost-adjusted returns measured by alpha from CAPM, the academic literature has accumulated a vast number of studies dedicated to evaluating the effectiveness of mutual funds. The issues related to the characteristics of investment portfolio managers have been considered important streams in the analysis of the results achieved by collective investment institutions. Managerial attributes include, among others, socio-demographic factors and improvement of professional qualifications through various certifications of finance management skills.

One of the most fundamental factors in social sciences is a gender. The difference between men and women are also discernible in finance. As was shown in the relevant literature, men and women differ as far as the perception of money, risk, and investment is concerned (Barber \& Odean, 2001). Nevertheless, risk aversion aspects should not be compared between professional portfolio management and common stock investment. The studies which deserve a mention in the context of mutual fund performance analysis include ones by Atkinson, Baird, \& Frye (2003) or Niessen \& Ruenzi (2006). The former, based on a sample including, among others, 72 female portfolio managers, did not identify any significant differences in the performance of fixed-income mutual funds. Atkinson, Baird, \& Frye noticed that female-managed funds had significantly lower inflows in the first year of managing a particular fund. The two main con- 
clusions mentioned above were virtually repeated in the research by Niessen \& Ruenzi (2006) for 13,547 fund-year observations, 1,472 of which with a female manager. The study was conducted for US bond and equity funds.

As regards more recent studies dedicated to the discussed topic, the work by Niessen-Ruenzi \& Ruenzi (2013) is worth mentioning as the authors collected 16,509 fund-year observations, 14,804 of which covered male managers and 1,705 - female ones. Relying on the data from the period 1992-2009, they noticed that female fund managers followed more persistent investment styles than male managers and that their performance was virtually identical.

Welch \& Wang (2013), in turn, analysed the effectiveness of 2,217 funds in order to establish the influence of changes on the position of portfolio manager on the achieved performance depending on gender. The measures applied in that research were one-, three- and four-factor asset pricing models enriched, among others, with the gender variable or a change in the composition of managers with respect to gender. By examining the effectiveness of funds in the period 1984-2004, they showed that gender differences were not a source of abnormal returns.

All of the above results concerned, however, the American market. Studies dedicated to the European market are scarce in the relevant literature mainly due to the fact that the number of women in the industry is still marginal. From among the few existing works, one by Babalos, Caporale, \& Philippas (2015), who analysed the results of 358 equity funds from France, Germany, Italy, and Spain operating in the period 2006-2011, deserves attention. They revealed that gender did not influence fund performance and women were not more risk averse than men. Therefore, we decided to formulate our first two hypotheses regarding returns as follows:

Hypothesis 1: There is no difference between funds managed by men and funds (co-)managed by women with respect to returns obtained.

Hypothesis 2: There is no significant relationship between a manager's gender and the managed fund performance.

The obtained certifications attesting qualifications were also one of the factors perceived as an advantage in the acquired management skills. According to the theory of human capital, better professional skills of a manager should correspond with better investment results. The most popular and desired certification attesting the abilities to manage investment portfolios is the Chartered Financial Analyst diploma (CFA). However, there are also other professional credentials for those who pursue finance and investment management careers, i.e. Certified International Investment Analyst (CIIA), Chartered Portfolio Manager (CPM), and Chartered Alternative Investment Analyst (CAIA), albeit they are extremely rarely taken into consideration in studies. 
Most of the findings related to examining the effect of professional credentials on performance, which come from the American market, did not provide any statistically significant results. For example, one of the first studies, Shukla $\&$ Singh (1994), analysed a sample of 223 funds divided into two groups of approximately equal sizes, one with at least one manager holding a CFA certificate and the other one with none of the mangers being a CFA charterholder. Their study covered the period 1988-1992. Similarly, Andreu \& Pütz (2012) analysed the effect of holding not only a CFA certificate but also an MBA degree on the results of equity funds for a subsequent period, i.e. 1996-2009. In the research, they used a set of performance metrics, including the raw return, alphas resulting from the single-index model (Jensen's alpha), the Fama-French three-factor model, and the Carhart four-factor model. Gregory-Allen \& Shawky (2018) also measured the results and risks for equity and mixed funds classified into several segments with homogenous investment profiles by means of the unadjusted return, the Jensen alpha, the Carhart measure, the beta coefficient and the tracking error in the period 2005-2007. The researchers did not find any significant differences in returns between MBA and CFA holders.

Switzer \& Huang (2007) were the first to provide conclusive evidence that fund managers holding CFA certificates achieved better investment results than, for instance, fund managers holding MBA degrees based on 1,004 US small and mid-cap equity funds. Similar conclusions can be found in studies from developing markets, e.g. Fang \& Wang (2015). Having analysed the performance of 287 Chinese funds operating in the period 2008-2011, they upheld the arguments presented in the theory of human capital and proved that managers holding both CFA certificates and MBA degrees seemed to provide higher rates of return to their clients. These results were obtained with the use of measures of abnormal returns, concerning stock picking ability, and excess returns. Nonetheless, Fan $\&$ Mazumder (2017), who examined the performance of 365 domestic US equity funds operating in the period 2009-2013, documented that funds with a higher level of managers' qualifications underperformed. Moreover, managers with MBA degrees performed moderately better than managers with CFA designations. The researchers used a set of eight measures of return as dependent variables. Hence, our next hypotheses read as:

Hypothesis 3: There is no difference between managers with or without CFAs with respect to returns obtained.

Hypothesis 4: There is no significant relationship between holding a CFA certificate by a manager and the managed fund performance. 
The issue of a relationship between fund performance and managerial characteristics is investigated in more developed markets, especially in the USA. The studies of investment fund industries in European markets focusing on the analysed issue are very scarce. Therefore, the paper by Filip (2020), who examined the influence of managerial factors of Polish portfolio managers on investment risk, is worth mentioning at this point. He revealed that demographic attributes as well as educational and carrier trajectory characteristics affected the risk level. Other studies remain unknown and, to our knowledge, it is the first paper to evaluate the performance of Polish investment funds in relation to managerial attributes.

\section{Data and empirical design}

The source of data on unit prices and names of Polish investment fund managers is Analizy Online (2018) but the remaining information comes from a proprietary database. The entire procedure of data gathering with unique variables describing a portfolio manager's profile was clarified in our previous study (Filip, 2018b). However, it needs to be indicated that the data supplier provided biographical notes about the managers only in some cases. For others, appropriate information had to be obtained from various public sources, e.g. the social media, websites of investment funds, lists of charterholders published on the website of CFA Institute etc. The employed set of investment fund characteristics covers two variables for a relatively large study sample, including 275 managers of 98 domestic equity funds operating in Poland. The time span was the period 2000-2017.

Due to an insufficient number of women managing funds independently (merely $3.6 \%$ of the group), the conducted study was aimed to capture the femininity aspect in the performance achieved by investment funds regardless of whether they were managed by women individually or collectively as part of the investment committee. As follows from the statistical description of the sample, women managed funds on their own in only 10 out of 86 annual observations aimed at spotting female managers. In other cases, they were team members. For the sake of comparison, Atkinson, Baird, \& Frye (2003) reported a 5.6\% share of women in their sample, in the study by Niessen-Ruenzi \& Ruenzi (2013) women constituted 10\%, while Babalos, Caporale, \& Philippas (2015) performed their analysis with a $16.5 \%$ share of female professionals. To conclude, we decided to group funds into those (co-)managed by women and those hiring only men to 
manage portfolios in order to capture the aspects of femininity and gender diversity. The first group consists of female-managed and mixed-gender funds. We are aware of the simplification, but given the fact that this branch is strongly dominated by men, any statistical inference would be ungrounded if it relied on those few observations of women managing funds on their own.

For the other variable under examination, the group of CFA charterholders was composed of independent fund managers and portfolio management team members. In other words, the managers from the sample were classified into two groups: a group with at least one manager with a CFA designation, and a group in which none of the managers was CFA-designated. A similar classification was adopted by Shukla \& Singh (1994). Moreover, in order to provide a more detailed analysis and, at the same time, to assess the robustness of the results, the study sample was reduced to solo-managed funds. Therefore, the same research hypothesis was subjected to verification, yet with alternative assumptions, namely the subsample was divided into funds managed by CFA charterholders and funds managed by non-CFAs. Nevertheless, the idea of dividing team funds into ones with a predominant percentage of CFA holders and others where managers with the certificate were in the minority or absent is equally interesting. Such a modification of the study should, however, be postponed since the number of charterholders among portfolio managers is still low. Yet, it will probably become possible in a near future due to the increasing popularity of the certificate, which has been noticeable recently. It is worth mentioning that $82(30 \%)$ out of 275 managers from our sample declared having a CFA designation.

A set of three tools can be used to present the planned research procedure. The diversity of methods ensures greater certainty of statistical inference. Two of the approaches belong to the group of inferential methods. In this case, the univariate analysis is carried out based on the difference in means and the differences in distributions of rates of return among subgroups of funds classified by variables describing a manager's gender and professional credentials. The test applied to the examination of the significance of the difference in means in two samples, which assumes unequal variances, was the well-known $t$-test in the following form:

$$
t=\frac{\overline{r_{A}}-\overline{r_{B}}}{\sqrt{\frac{\sigma_{A}^{2}}{n_{A}}+\frac{\sigma_{B}^{2}}{n_{B}}}}
$$


where: $\overline{r_{A}}$ and $\overline{r_{B}}$ are the mean values of the rate of return in the first (A) and the second sample (B); $\sigma_{A}^{2}$ and $\sigma_{B}^{2}$ are the standard deviations of the rates of return for funds classified into the former groups and the latter groups respectively; $n_{A}$ and $n_{B}$ are the sizes of the mentioned samples. The distribution of statistics $t$ depends on the size of the samples. The null hypothesis on the equal mean of the rate of return in funds classified into groups A and B can be rejected when the absolute value of statistics $t$ calculated from the sample is higher than the critical value for a given significance level with the number of degrees of freedom given by the following formula (Kanji, 2006):

$$
v=\frac{\left(\frac{\sigma_{A}^{2}}{n_{A}}+\frac{\sigma_{B}^{2}}{n_{B}}\right)^{2}}{\frac{\sigma_{A}^{4}}{n_{A}^{2}\left(n_{A}-1\right)}+\frac{\sigma_{B}^{4}}{n_{B}^{2}\left(n_{B}-1\right)}}
$$

In other words, the rejection of the null hypothesis suggests that the difference between the mean values in the analysed groups is statistically significant. A positive value of the variable expressed by formula (1) supports the arguments that better performing funds are managed only by men or managers without CFA designations. The negative value, in turn, is in favour of the arguments that teams with female members outperform male-managed funds or that funds with CFA holders perform better.

The Mann-Whitney $U$ test with continuity correction was applied to testing differences in distributions for two independent samples. The null hypothesis for the Mann-Whitney $U$ test states that, in general, two samples come from the same population (i.e. have the same median). The non-parametric test is a proper tool in the case of data that are not normally distributed and may include many outliers. In this approach, all data from the two groups should be merged into one, sorted from the lowest to the highest value and, finally, ranked in the list. The Mann-Whitney test statistic is calculated by means of the $U$ value as:

$$
U_{1}=n_{A} n_{B}+\frac{n_{A}\left(n_{A}+1\right)}{2}-R_{A}
$$

where: $R_{A}$ or $R_{B}$ are the adjusted rank sums for sample $\mathrm{A}$ and $\mathrm{B}$, respectively. 
The value of the $Z$-score for the Mann-Whitney $U$ test is calculated as follows:

$$
Z=\frac{U-\frac{n_{A} n_{B}}{2}-0.5}{\sqrt{\frac{n_{A} n_{B}\left(n_{A}+n_{B}+1\right)}{12}}}
$$

The above approaches permit an answer to the question if there are any differences in the performance of funds managed by individuals with a few diverse socio-demographic characteristics. The third research procedure, in turn, is used to determine the impact of the selected features on abnormal returns achieved by fund managers (cf. Welch \& Wang, 2013). The relatively high number of observations enables the use of panel models consisting of a time series for each cross-sectional entity in the data set to this end. The employed estimation procedure is static models with fixed effects (FEM) using dummy variables. The FEM's estimation seemed the most adequate for the gathered data after running diagnostics by means of the Hausman statistic.

The nature of the applied models with gender used as a proxy is specified as follows:

$$
\begin{aligned}
\operatorname{perf}_{i, t} & =\alpha_{i}+\beta_{1, i} \text { Gender }_{i, t}+\beta_{2, i} M K T_{t} \\
\operatorname{perf}_{i, t} & =\alpha_{i}+\beta_{1, i} \text { Gender }_{i, t}+\beta_{2, i} M K T_{t}+\beta_{3, i} S M B_{t}+\beta_{4, i} H M L_{t}+\beta_{5, i} U M D_{t} \\
\operatorname{perf}_{i, t} & =\alpha_{i}+\beta_{1, i} \text { Gender }_{i, t}+\beta_{2, i} M K T_{t}+\beta_{3, i} S M B_{t}+\beta_{4, i} H M L_{t}+\beta_{5, i} R M W_{t}+\beta_{6, i} C M A_{t},
\end{aligned}
$$

The models where the CFA designation was used as one of the regressors of investment performance assumed the following form:

$$
\begin{aligned}
& \operatorname{perf}_{i, t}=\alpha_{i}+\beta_{1, i} C F A_{i, t}+\beta_{2, i} M K T_{t}, \\
& \operatorname{perf}_{i, t}=\alpha_{i}+\beta_{1, i} C F A_{i, t}+\beta_{2, i} M K T_{t}+\beta_{3, i} S M B_{t}+\beta_{4, i} H M L_{t}+\beta_{5, i} U M D_{t}, \\
& \operatorname{perf}_{i, t}=\alpha_{i}+\beta_{1, i} C F A_{i, t}+\beta_{2, i} M K T_{t}+\beta_{3, i} S M B_{t}+\beta_{4, i} H M L_{t}+\beta_{5, i} R M W_{t}+\beta_{6, i} C M A_{t} .
\end{aligned}
$$

The variables which were factors in asset pricing models occurred in each of the said six models. Starting with the one-index model, the return on the local equity market benchmark (MKT) in period $t$ was calculated on the basis of the values of the main Warsaw Stock Exchange Index (WIG). Other factors for the Polish stock market were the following mimicking portfolios: $S M B, H M L$, and $U M D$ from the Carhart approach (Carhart, 1997) as well as $S M L, H M L, R M W$, and CMA from the Fama-French methodology (Fama \& French, 2015). They were (cf. Zaremba, Czapkiewicz, Szczygielski, \& Kaganov, 2019): 
- SMB (Small Minus Big) being the average difference between the return on the three small portfolios and the return on the three big portfolios,

- HML (High Minus Low) being the average difference between the return on the two value portfolios and the return on the two growth portfolios,

- UMD (Up Minus Down) being the average difference between the return on the two high prior return portfolios and the return on the two low prior return portfolios,

- $R M W$ (Robust Minus Weak) being the average difference between the return on the two high profitability portfolios and the return on the two low profitability portfolios,

- CMA (Conservative Minus Aggressive) being the average difference between the return on the two low investment portfolios and the return on the two high investment portfolios.

The data concerning all of the above-mentioned benchmarks for the Polish stock market were gathered from Adam Zaremba's website (2018), where values of mimicking portfolios are reported. A risk-free rate of return was the weighted average yield on 13-week T-bills, one of the most popular short-term debt instruments, offered at regular auctions held by the National Bank of Poland for the institutional investors. Its values were obtained from the International Financial Statistics quarterly reports prepared by the International Monetary Fund. Monthly returns on the main local market index (WIG) were obtained from the Warsaw Stock Exchange website.

This paper examines the relationship between fund performance and demographic and professional credentials by using a set of performance metrics. The applied performance ratios are listed below:

- RawReturn is a compounded return calculated as a logarithmic rate of return,

- Sharpe is a classic ratio calculated as an excess return in relation to unsystematic risk,

- Treynor is a classic ratio calculated as an excess return in relation to systematic risk,

- Sortino is a classic ratio calculated as an excess return in relation to downside risk,

- IR is an information ratio calculated as an excess return in relation to a tracking error,

- Jensen is a stock selection measure calculated as an intercept of a single-index model with a local stock index (WIG) as a benchmark, 
- Fama-French is a stock selection measure calculated as an intercept of a three-factor model (Fama \& French, 1993) including size and value mimicking portfolios,

- Carhart is a stock selection measure calculated as an intercept of a four-factor model with the momentum mimicking portfolio added to the previous mentioned measure,

- Treynor-Mazuy is a stock selection and market timing measure calculated as an intercept of the quadratic regression model with the curvature of the security market line,

- Henriksson-Merton is a stock selection and market timing measure calculated as an intercept of the regression model with a parameter referring to two different market trends (bull market and bear market).

Fund returns were calculated by computing the change in the monthly net asset value. Excess returns, in turn, were calculated with respect to the wholesale instruments dedicated for the institutional investor groups (13-week T-bill interest rates), and the monthly prices of the benchmark indices were obtained from the Warsaw Stock Exchange. Due to the constraints on the volume of this paper, we decided to omit well-known formulas of the above mentioned metrics, which are standard ratios used in empirical studies on fund performance.

\section{Empirical results}

The differences in the investment results achieved by two groups of funds classified by gender (Panel A) and CFA (Panel B and C) variables were observed with the use of the $t$-test for means. We decided to use 10 measures of returns, including continuously compounded, risk-adjusted and abnormal returns (cf. de Souza, 2013). Table 1 presents the expected differences between means of returns in two subsamples. 
Table 1. The differences between means in two samples assuming unequal variances

Panel A: Gender as a grouping variable

\begin{tabular}{|c|c|c|c|c|c|c|c|}
\hline measure of return & $\begin{array}{l}\text { Mean valu } \\
\text { among } \\
\text { managed by } \\
\text { men }\end{array}$ & $\begin{array}{l}\text { e of return } \\
\text { funds: } \\
\text { (co-)managed } \\
\text { by women }\end{array}$ & $\begin{array}{c}t \text {-test for } \\
\text { means }\end{array}$ & $\begin{array}{c}p(T<=t) \\
\text { one-tail }\end{array}$ & $\begin{array}{c}t \text { Critical } \\
\text { one-tail }\end{array}$ & $\begin{array}{c}p(T<=t) \\
\text { two-tail }\end{array}$ & $\begin{array}{c}t \text { Critical } \\
\text { two-tail }\end{array}$ \\
\hline RawReturn & 0.03063 & 0.02034 & 0.34045 & 0.36710 & 1.65936 & 0.73419 & 1.98260 \\
\hline Sharpe & 0.02143 & -0.00110 & 0.45729 & 0.32421 & 1.65964 & 0.64842 & 1.98304 \\
\hline Treynor & 0.04475 & 0.02280 & 0.62931 & 0.26526 & 1.65950 & 0.53052 & 1.98282 \\
\hline Sortino & 0.22557 & 0.04902 & 1.69552 & 0.04560 & 1.65090 & 0.09121 & 1.96938 \\
\hline IR & -0.10372 & -0.11515 & 0.30746 & 0.37954 & 1.65895 & 0.75908 & 1.98197 \\
\hline Jensen & -0.00043 & -0.00143 & 1.02679 & 0.15343 & 1.65936 & 0.30686 & 1.98260 \\
\hline Fama-French & 0.00080 & 0.00009 & 0.81490 & 0.20847 & 1.65922 & 0.41694 & 1.98238 \\
\hline Carhart & -0.00062 & -0.00220 & 1.87424 & 0.03178 & 1.65882 & & 1.98177 \\
\hline Treynor- & 0.00051 & -0.00056 & 0.83612 & 0.20251 & 1.65978 & 0.40502 & 1.98326 \\
\hline Henriks son-Merton & 0.00187 & 0.00120 & 0.44070 & 017 & & 0.6 & 1.98282 \\
\hline \multicolumn{8}{|c|}{ Panel B: CFA as a grouping variable in the total sample } \\
\hline meas & $\begin{array}{r}\text { Mean valu } \\
\text { among } \\
\text { managed by } \\
\text { non-CFAs }\end{array}$ & $\begin{array}{l}\text { e of return } \\
\text { funds: } \\
\text { (co-)managed } \\
\text { by CFAs }\end{array}$ & $\begin{array}{c}t \text {-test for } \\
\text { means }\end{array}$ & $\begin{array}{c}p(T<=t) \\
\text { one-tail }\end{array}$ & $\begin{array}{c}t \text { Critical } \\
\text { one-tail }\end{array}$ & $\begin{array}{c}p(T<=t) \\
\text { two-tail }\end{array}$ & $\begin{array}{c}t \text { Critical } \\
\text { two-tail }\end{array}$ \\
\hline RawReturn & 0.02948 & 0.02963 & -0.00819 & 0.49673 & 1.64690 & 0.99346 & 1.96314 \\
\hline Sharpe & 0.01498 & 0.02225 & -0.24740 & 0.40233 & 686 & 0.8 & 1.96309 \\
\hline Treynor & 0.03554 & 0.04777 & -0.57327 & 0.28332 & 1.64694 & 0.56664 & 1.96321 \\
\hline Sortino & 0.18428 & 0.22489 & -0.33357 & 0.36940 & 1.64670 & 0.73879 & 1.96284 \\
\hline IR & -0.09537 & -0.11215 & 0.68782 & 0.24588 & 1.64683 & 0.4 & 1.96304 \\
\hline Jensen & -0.00072 & -0.00039 & -0.53436 & 0.29663 & 1.64706 & 0.5 & 1.96340 \\
\hline Fama-French & 0.00087 & 0.00061 & 0.46122 & 0.32239 & 1.64709 & 0.64479 & 1.96344 \\
\hline Carhart & -0.00046 & -0.00103 & 0.97982 & 0.16377 & 1.64718 & 754 & 1.96358 \\
\hline Treynor & 0.00012 & 0.00061 & -0.63863 & 0.26164 & 1.64702 & 0.52327 & 1.96334 \\
\hline Henriks son-Merton & 0.00161 & 0.00194 & -0.36142 & 0.35894 & 694 & 789 & 1.96321 \\
\hline \multicolumn{8}{|c|}{ Panel C: CFA as a grouping variable in the subsample of solo-managed funds } \\
\hline measure of return & $\begin{array}{l}\text { Mean value of return } \\
\text { among funds: }\end{array}$ & $\begin{array}{l}\text { e of return } \\
\text { funds: } \\
\text { managed by } \\
\text { CFAs }\end{array}$ & $\begin{array}{c}t \text {-test for } \\
\text { means }\end{array}$ & $\begin{array}{c}p(T<=t) \\
\text { one-tail }\end{array}$ & $\begin{array}{c}t \text { Critical } \\
\text { one-tail }\end{array}$ & $\begin{array}{c}p(T<=t) \\
\text { two-tail }\end{array}$ & $\begin{array}{c}t \text { Critical } \\
\text { two-tail }\end{array}$ \\
\hline RawReturn & 0.02244 & 0.07209 & -1.73104 & 0.04227 & 1.65024 & 0.08453 & 1.96835 \\
\hline Sharpe & 0.00524 & 0.09497 & -2.00570 & 0.02294 & 1.65050 & 0.04588 & 1.96876 \\
\hline Treynor & 0.03252 & 0.09029 & -1.76028 & 0.03973 & 1.65031 & 0.07945 & 1.96847 \\
\hline Sortino & 0.20097 & 0.53926 & -1.03801 & 0.15048 & 1.65521 & 0.30096 & 1.97612 \\
\hline IR & -0.08992 & -0.13633 & 1.30338 & 0.09681 & 1.65090 & 0.19363 & 1.96938 \\
\hline Jensen & -0.00071 & 0.00007 & -0.87073 & 0.19227 & 1.64944 & 0.38453 & 1.96711 \\
\hline & 0.00101 & 0.00153 & -0.60576 & 0.27256 & 1.64982 & 0.54512 & 1.96770 \\
\hline Carhart & 0.00008 & 0.00030 & -0.24285 & 0.40414 & 1.64980 & 0.80828 & 1.96767 \\
\hline Treynor & -0.00017 & 0.00070 & -0.80483 & 0.21075 & 1.64957 & 0.42151 & 1.96731 \\
\hline Henriks s on-Merton & 0.00126 & 0.00099 & 0.20110 & 0.42038 & 1.65000 & 0.84076 & 1.96798 \\
\hline
\end{tabular}

Source: Author's own calculation.

The first approach applied is the method of univariate analysis. Findings coming from this method can be treated as part of an exploratory data analysis. As was presented in Table 1 (Panel A), the two independent samples $t$-test analysing differences between means, where gender was a grouping variable, pro- 
vide relatively explicit results that enable the confirmation of the hypothesis on the lack of significant differences between means of returns in the two subsamples. The division into male-managed funds versus female-managed and mixed-gender funds did not result in significant differences in returns. It means that the element of femininity in fund management teams was absolutely insignificant for generating investment results. However, for all ratios, the mean values of return were slightly higher among funds managed only by men. Only the statistically significant results achieved with the application of the Sortino ratio and the Carhart measure as measures of return deserve further explanations. Nevertheless, conducting the $t$-test where gender was a grouping variable, we have to stress that one of the main assumptions, with respect to the adequacy of sample size, was violated. Thus, the results should be treated with reserve.

In relation to a CFA designation as a professional credential, the obtained results are even clearer (Panel B). There were no statistically significant differences in means of returns between funds hiring managers without professional certifications and funds cooperating with CFA managers in all tests employed. It seems that CFA charterholders working independently or in teams perform at the same level as managers or teams without a CFA designation. Nonetheless, it should be noted that after limiting the study sample to solo-managed funds only (Panel C), the managers holding prestigious professional qualifications significantly outperformed their peers in a few cases where the performance was measured by means of basic metrics (raw return, Sharpe ratio and Treynor ratio). The conducted tests concerning other measures, in particular ones applying mimicking portfolios or assessment of market timing skills, did not indicate any significant differences. The investigation ought to be continued with other methods.

As before, our sample was divided into two subsamples. The classification criteria were gender (Panel A) and CFA (Panel B and C). This time, the differences in investment results of unequal groups of funds were observed through the Mann-Whitney $U$ test with correction for continuity. It is possible to conduct robustness checks by applying a selected set of measures of returns. Table 2 presents the expected differences between the distributions in two populations. 
Table 2. The differences in distributions of samples calculated with the use of the Mann-Whitney $U$ test

Panel A: Gender as a grouping variable

\begin{tabular}{l|cccccccccc}
\hline \multicolumn{1}{c}{ measure of return } & $\begin{array}{c}\text { Rank sum for funds: } \\
\text { managed } \\
\text { by men }\end{array}$ & $\begin{array}{c}\text { (co-)managed } \\
\text { by women }\end{array}$ & $U$ & & $Z$ & $p$-value & $Z$ adjusted & $p$-value $\begin{array}{c}\text { Valid N: } \\
\text { funds } \\
\text { managed by } \\
\text { men }\end{array}$ & $\begin{array}{c}\text { Valid N: } \\
\text { funds (co-) } \\
\text { managed by } \\
\text { women }\end{array}$ \\
\hline RawReturn & 311747 & 35614 & 31873 & 0.11713 & 0.90676 & 0.11713 & 0.90676 & 747 & 86 \\
Sharpe & 311987 & 35374 & 31633 & 0.23071 & 0.81754 & 0.23071 & 0.81754 & 747 & 86 \\
Treynor & 311866 & 35495 & 31754 & 0.17345 & 0.86230 & 0.17345 & 0.86230 & 747 & 86 \\
Sortino & 309008 & 35027 & 31286 & 0.31513 & 0.75266 & 0.31513 & 0.75266 & 743 & 86 \\
IR & 312110 & 35251 & 31510 & 0.28892 & 0.77264 & 0.28892 & 0.77264 & 747 & 86 \\
Jensen & 314003 & 33358 & 29617 & 1.18480 & 0.23610 & 1.18480 & 0.23610 & 747 & 86 \\
Fama-French & 311827 & 35534 & 31793 & 0.15499 & 0.87683 & 0.15499 & 0.87683 & 747 & 86 \\
Carhart & 314350 & 33011 & 29270 & 1.34902 & 0.17733 & 1.34902 & 0.17733 & 747 & 86 \\
Treynor-Mazuy & 312986 & 34375 & 30634 & 0.70350 & 0.48175 & 0.70350 & 0.48175 & 747 & 86 \\
Henriksson-Merton & 313158 & 34203 & 30462 & 0.78490 & 0.43251 & 0.78490 & 0.43251 & 747 & 86 \\
\hline
\end{tabular}

Panel B: CFA as a grouping variable in the total sample

\begin{tabular}{|c|c|c|c|c|c|c|c|c|c|}
\hline measure of return & $\begin{array}{l}\text { Rank sun } \\
\text { managed } \\
\text { by non- } \\
\text { CFAs }\end{array}$ & $\begin{array}{l}\text { m for funds: } \\
\text { (co-)managed } \\
\text { by CFAs }\end{array}$ & $U$ & $Z$ & $p$-value & $Z$ adjusted & $p$-value & $\begin{array}{c}\text { Valid } \mathrm{N} \text { : } \\
\text { funds } \\
\text { managed by } \\
\text { non-CFAs }\end{array}$ & $\begin{array}{c}\text { Valid N: } \\
\text { funds (co-) } \\
\text { managed by } \\
\text { CFAs }\end{array}$ \\
\hline RawReturn & 150767 & 196594 & 84493 & 0.18793 & 0.85093 & 0.18793 & 0.85093 & 360 & 473 \\
\hline Sharpe & 149071 & 198290 & 84091 & -0.30479 & 0.76053 & -0.30479 & 0.76053 & 360 & 473 \\
\hline Treynor & 148353 & 199008 & 83373 & -0.51350 & 0.60760 & -0.51350 & 0.60760 & 360 & 473 \\
\hline IR & 152564 & 194797 & 82696 & 0.71029 & 0.47752 & 0.71029 & 0.47752 & 360 & 473 \\
\hline Jensen & 150846 & 196515 & 84414 & 0.21089 & 0.83297 & 0.21089 & 0.83297 & 360 & 473 \\
\hline Fama-French & 150553 & 196808 & 84707 & 0.12572 & 0.89995 & 0.12572 & 0.89995 & 360 & 473 \\
\hline Carhart & 154187 & 193174 & 81073 & 1.18208 & 0.23718 & 1.18208 & 0.23718 & 360 & 473 \\
\hline Treynor-Mazuy & 149771 & 197590 & 84791 & -0.10130 & 0.91931 & -0.10130 & 0.91931 & 360 & 473 \\
\hline
\end{tabular}

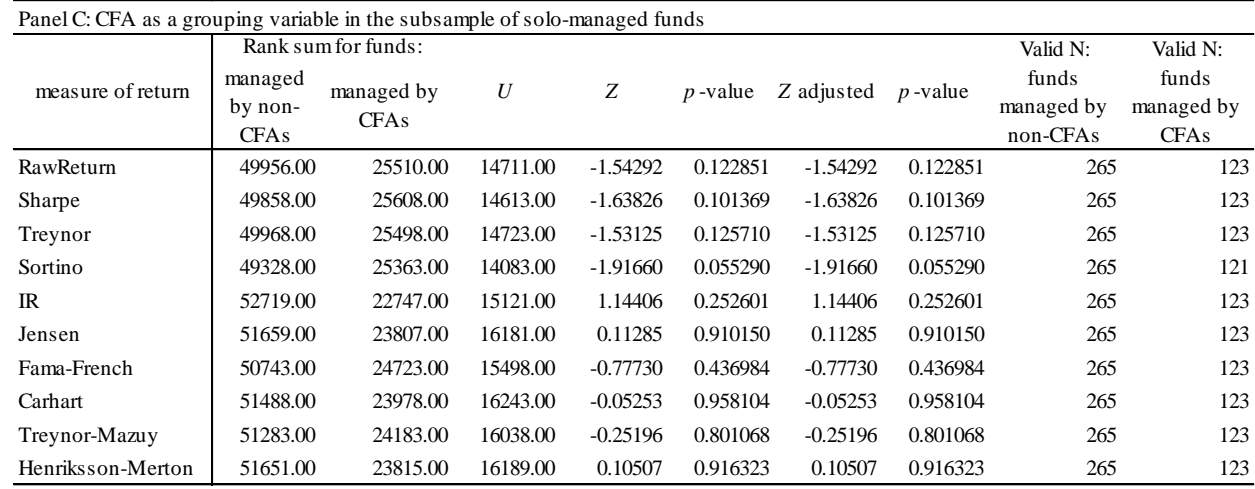

Source: Author's own calculation.

The Mann-Whitney $U$ test might be treated as an alternative test to the independent sample $t$-test. However, the results are similar to the previous ones in most cases. The verified hypothesis on the lack of significant differences between the distributions of the analysed variables in two subsamples should be 
confirmed. There were no differences in the returns achieved by funds managed by men and ones (co-)managed by women (Panel A) as well as funds employing managers with and without professional certifications, such as a CFA designation. It means that the subsamples come from the same population. Nevertheless, it should be remembered that in the second analysed subsample of funds, CFAdesignated solo managers and teams of managers were placed in one group (Panel B). However, when the sample of funds was reduced to solo-managed ones only (Panel C), the test comparing performance in the two independent subsamples did not indicate any differences in the results of unequal groups of funds for all measures of return but the Sortino ratio. In general, this implies that a CFA designation still should not be considered the key factor determining the investment decisions made by clients of investment funds. Moreover, disregarding the obtained results, the performance analysis of portfolio managers alone rather than that of investment funds as subjects of investigation seems to be an interesting empirical topic which deserves consideration.

In order to specify the influence of the selected managerial characteristics on abnormal returns, the next research procedure was based on the most popular multifactor asset pricing models applied in studies of fund performance. The estimations enable the determination whether the predictor of the investment results achieved by funds, apart from mimicking portfolios, could be gender diversity (Panel A) and CFA (Panel B and C) independently. The findings with this respect are presented in Table 3.

Table 3. Significance of gender and professional credentials factors in performance of investment fund managers

\begin{tabular}{|c|c|c|c|c|}
\hline & $\begin{array}{c}\text { one-index model } \\
\text { (1) }\end{array}$ & $\begin{array}{c}\text { four-factor model } \\
\text { (2) } \\
\end{array}$ & $\begin{array}{c}\text { five-factor mode } \\
\text { (3) }\end{array}$ & \\
\hline const & $\begin{array}{rl}-0,019562 & * * * * \\
(0.002274) & \end{array}$ & $\begin{array}{r}-0,005350 \\
(0.005586)\end{array}$ & $\begin{array}{r}-0,002305 \\
(0.003599)\end{array}$ & \\
\hline$\beta_{\text {Gender }}$ & $\begin{array}{r}0,001876 \\
(0.019222)\end{array}$ & $\begin{array}{r}0,006429 \\
(0.018135)\end{array}$ & $\begin{array}{r}0,007305 \\
(0.018330)\end{array}$ & \\
\hline$\beta_{M K T}$ & $\begin{array}{rl}0,948723 & * * * \\
(0.021071) & \end{array}$ & $\begin{array}{rl}0,885299 & * * * * \\
(0.022596) & \end{array}$ & $\begin{array}{r}0,890031 \\
(0.022434)\end{array}$ & **** \\
\hline$\beta_{S M B}$ & & $\begin{array}{rl}3,194120 & * * * * \\
(0.382100) & \end{array}$ & $\begin{array}{r}3,294170 \\
(0.372477)\end{array}$ & $* * *$ \\
\hline$\beta_{H M L}$ & & $\begin{aligned}-0,971821 & \text { ***** } \\
(0.357572) & \end{aligned}$ & $\begin{array}{l}-1,092150 \\
(0.272327)\end{array}$ & $* * *$ \\
\hline$\beta_{U M D}$ & & $\begin{array}{r}0,045774 \\
(0.204571)\end{array}$ & & \\
\hline$\beta_{R M W}$ & & & $\begin{array}{c}-0,410866 \\
(0.438405)\end{array}$ & \\
\hline$\beta_{C M A}$ & & & $\begin{array}{r}0,109354 \\
(0.316032) \\
\end{array}$ & \\
\hline Funds & 98 & 98 & 98 & \\
\hline Observations & 833 & 833 & 833 & \\
\hline$R$-squared & 0,8410 & 0,8722 & 0,8724 & \\
\hline Adj. $R$-squared & 0,8312 & 0,8643 & 0,8645 & \\
\hline
\end{tabular}




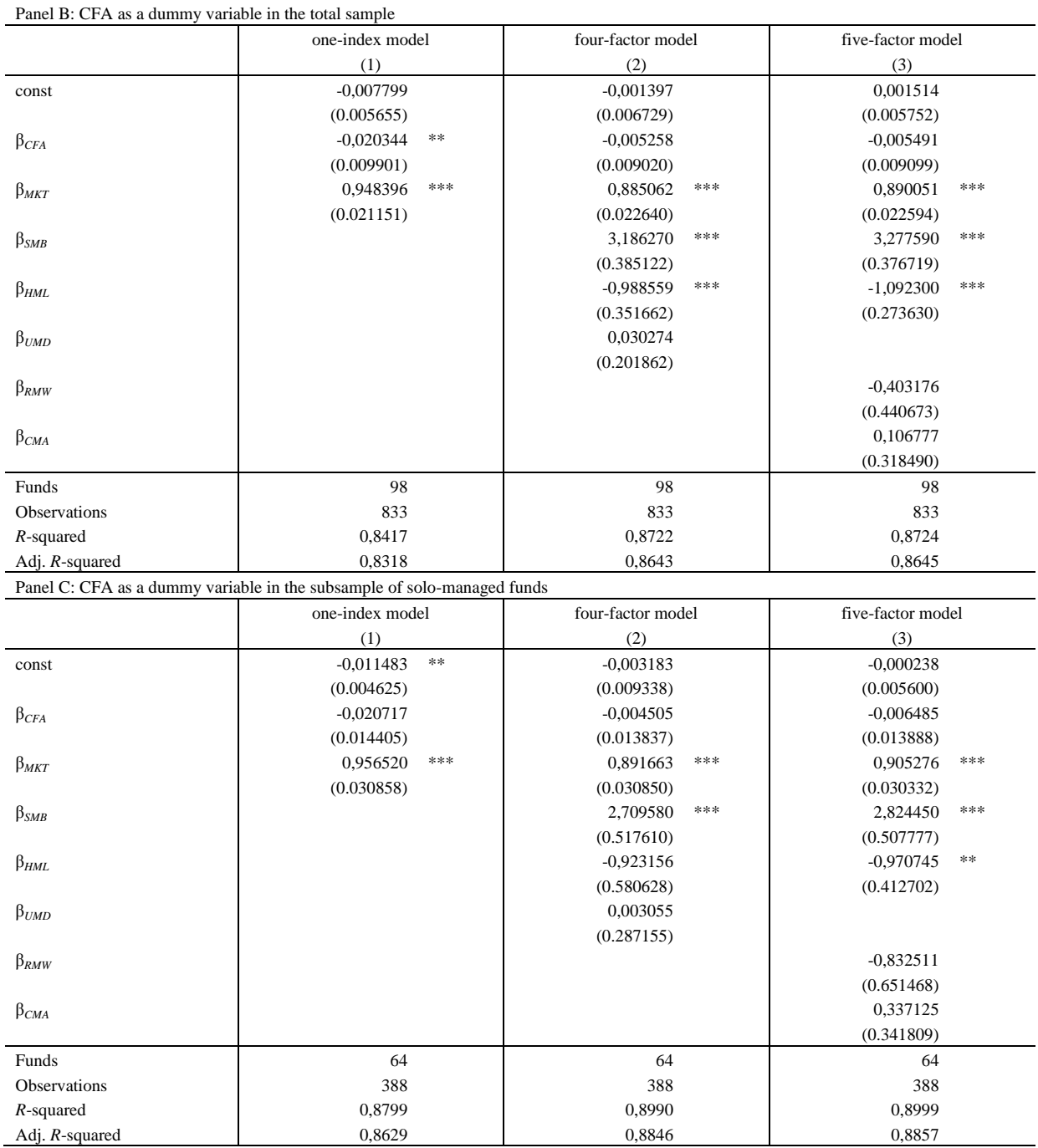

Note: Standard errors are shown in parentheses below. Coefficients. *, ** and $* * *$ indicate significance levels at 10,5 and $1 \%$, respectively.

Source: Author's own study.

Table 3 presents regression results with a gender and CFA as dummy variables. For the former characteristic, it cannot be confirmed in a statistically significant manner that a manager's gender might contribute to the abnormal returns generated by investment funds (Panel A). Hence, fund performance does not depend on the gender of the portfolio manager. This authenticates the earlier conclusions. As regards the latter attribute, a CFA designation turned out to be 
a proxy for abnormal returns but only for the one-index model, excluding mimicking portfolios (Panel B). Thus, a certain sensitivity of rates of return to the fact of holding or not CFA certificates by managers was noticed. Nonetheless, the conclusion was not robust to other specifications, e.g. ones concerning the division of the sample of solo-managed funds into funds managed by CFA charterholders and funds managed by persons without CFA diplomas (Panel C). Therefore, the ultimate results were ambiguous. When we applied four- and fivefactor models in both Panels (B and C), the influence was statistically insignificant. Hence, the obtained results deserve a further analysis applying more advanced research approaches or redefining the employed sample division criteria, e.g. in team-managed funds.

It should also be noted that the significant association of rates of return with changes in the stock index $(M K T)$ is understandable for the entities with equity securities prevailing in their portfolios. The employed models also revealed that the basic factors coming from the Fama-French model (Fama \& French, 1993) for the Polish stock market, i.e. $S M B$ and $H M L$, affected the returns achieved by fund managers. This could mean that they use the size and value premiums (cf. Filip, 2018a). Other mimicking portfolios were rather non-existent in investment fund performance.

In the initial version of the study, CIIA certificates and $\mathrm{PhD}$ degrees in economics and finance held by managers were used additionally as independent variables. Since the number of persons holding the educational $(\mathrm{PhD}-$ approx. 9.5\%) and professional (CIIA - approx. 2\%) credentials was low in the discussed group, and the practical implications for most of the employed performance measures were not statistically significant, and given the constraints on the volume of this study, we have not decided to include them. The estimates of the statistical models and the results of the examination of the differences for means and distributions of returns for CIIA and $\mathrm{PhD}$ variables are available from the author of this paper at request.

\section{Conclusions}

The purpose of this paper was to examine whether investment fund performance is related to managerial characteristics, such us a gender and professional credentials. Moreover, it was important to show the differences in the returns achieved by male-managed funds and female-managed and mixed-gender funds as well as the returns of funds managed by CFA holders and managers without 
the CFA designation. To this end, we employed a set of three approaches, including tests for the difference in the mean values and distributions of rates of return in two samples of funds, where gender and CFA were grouping variables, and regression models, where a gender or CFA were dummy factors implemented into the selected asset pricing models. The investigation was conducted for a relatively large study sample, including 275 managers of 98 domestic equity funds operating in Poland in the period 2000-2017.

The obtained results indicate that there are no performance disproportions between male and female managers as well as managers with and without CFA certificates. Moreover, the relationship between investment fund performance and managerial characteristics, such as a manager's gender, is insignificant. Thus, the first two hypotheses were fully confirmed. The results correspond well with the observations derived from Atkinson, Baird, \& Frye (2003) or Niessen \& Ruenzi (2006), who revealed the absence of differences in the returns achieved by male and female managers. In general, the next two hypotheses about the difference in returns of two independent groups as well the relationship of performance-professional credentials should also be confirmed. However, the findings related to the second variable were ambiguous when regression methods were applied. This is partly consistent with Gottesman \& Morey (2006), among others, in particular in the context of underperformance of fund managers with CFA designations. One possible explanation of our results is that CFA charterholders might exhibit a tendency to riskier strategies which does not always result in better performance (cf. Fan \& Mazumder, 2017). However, the study is not free from limitations. We are aware of certain simplifications concerning the selection of the research sample. The first step towards removing the limitations was to apply a modified study sample restricted to solo-managed funds. Therefore, further analysis should be extended to other sample division criteria, especially as regards team-managed funds.

The confrontation of the research findings resulting from the application of the three examination instruments seems to be an interesting issue for the study. Moreover, the originality of the research is evidenced by the application of a relatively expanded set of measures of return and the use of a proprietary database with unique variables describing a portfolio manager's profile. From the practical perspective, the results may be also of interest to both individual investors and fund families as a key factor in investment and human resource policy decisions respectively. 
The phenomenon of a relationship between fund performance and managerial attributes in the CEE countries is rarely investigated. To our knowledge, it is the first paper to evaluate the performance of Polish investment funds in relation to managerial characteristics. Hence, this paper is an attempt to fill in the existing research gap. However, the influence of the analysed issue deserves further analysis through advanced research approaches and, for instance, tests for subperiods, where relatively stable market trends were observed. Such an approach will aim at identifying potential managerial attributes which aid the achievement of the assumed goals in periods of a better and a worse market situation separately (cf. Detzel \& Weigand, 1998; Gottesman \& Morey, 2006). It would also be interesting to examine whether there is any difference between the predominant percentage of portfolio managers with a CFA title or not in fund investment committees with respect to the returns obtained or, alternatively, to use a measure of professional credentials diversity, e.g. the normalised Gibbs entropy, of the managers in team-managed mutual funds (cf. Tan \& Sen, 2019).

\section{Acknowledgements}

The author acknowledges the financial support of the National Science Center (NCN), Poland, project no. 2014/15/D/HS4/01227 entitled 'Determinants of Mutual Fund Performance: Managerial characteristics and fund attributes'.

\section{References}

Analizy Online. (2018). Investment funds evaluation. Retrieved from https://www. analizy.pl/fundusze/

Andreu, L., \& Pütz, A. (2012). Are two business degrees better than one? Evidence from mutual fund managers' education (Working Paper, No. 12-01). Cologne: Centre for Financial Research (CFR).

Atkinson, S. M., Baird, S. B., \& Frye, M. B. (2003). Do female mutual fund managers manage differently? The Journal of Financial Research, 26(1), 1-18. https:// doi.org/10.1111/1475-6803.00041

Babalos, V., Caporale, G. M., \& Philippas, N. (2015). Gender, style diversity, and their effect on fund performance. Research in International Business and Finance, 35, 57-74. https://doi.org/10.1016/j.ribaf.2015.02.020

Barber, B. M., \& Odean, T. (2001). Boys will be boys: Gender, overconfidence, and common stock investment. The Quarterly Journal of Economics, 116(1), 261-292. https:// doi.org/10.1162/003355301556400 
Carhart, M. M. (1997). On persistence in mutual fund performance. Journal of Finance, 52(1), 57-82, https://doi.org/10.1111/j.1540-6261.1997.tb03808.x

Detzel, F. L., \& Weigand, R. A. (1998). Explaining persistence in mutual fund performance. Financial Services Review, 7(1), 45-55. https://doi.org/10.1016/S10570810(99)80012-2

Fama, E. F., \& French, K. R. (1993). Common risk factors in the returns on stocks and bonds. Journal of Financial Economics, 33(1), 3-56. http://dx.doi.org/10.1016/ 0304-405X(93)90023-5.

Fama, E. F., \& French, K. R. (2015). A five-factor asset pricing model. Journal of Financial Economics, 116(1), 1-22. https://doi.org/10.1016/j.jfineco.2014.10.010

Fan, Y., \& Mazumder, M. I. (2017). CFA, MBA or both: Further evidence on mutual fund performance. Journal of Accounting and Finance, 17(7), 140-158.

Fang, Y., \& Wang, H. (2015). Fund manager characteristics and performance. Investment Analysts Journal, 44(1), 102-116. https://doi.org/10.1080/10293523. 2015.994453

Felício, A. J., Couto, E., \& Caiado, J. (2014). Human capital, social capital and organizational performance. Management Decision, 52(2), 350-364. https://doi.org/10.1108/ MD-04-2013-0260

Filip, D. (2018a). Wieloczynnikowe modele w analizie efektywności funduszy inwestycyjnych [Multifactor models in the analysis of mutual fund effectiveness]. Problemy Zarzadzania - Management Issues, 16(3/76), 61-81. https://doi.org/ 10.7172/1644-9584.76.5

Filip, D. (2018b). The profile of a Polish mutual fund manager. Journal of Economics and Management, 32(2), 30-47. https://doi.org/10.22367/jem.2018.32.03

Filip, D. (2020). Managerial factors in investment risk: Evidence from Polish mutual funds. e-Finanse. Financial Internet Quarterly (in print).

Gottesman, A. A., \& Morey, M. R. (2006). Manager education and mutual fund performance. Journal of Empirical Finance, 13(2), 145-182. https://doi.org/10. 1016/j.jempfin.2005.10.001

Gregory-Allen, R. B., \& Shawky, H. A. (2018). Are you smarter than a CFA'er? Manager qualifications and portfolio performance. International Journal of Accounting and Financial Reporting, 8(1), 305-324, https://doi.org/10.5296/ijafr.v8i1.12832

Jensen, M. (1968). The performance of mutual funds in the period 1945-1964. Journal of Finance, 23(2), 389-416. https:// doi.org/10.1111/j.1540-6261.1968.tb00815.x

Kanji, G. K. (2006). 100 Statistical tests (third edition). London, Thousand Oaks, New Delhi: Sage Publications.

Niessen, A., \& Ruenzi, S. (2006). Sex matters: Gender and mutual funds (Working Paper, No. 06-01). Cologne: Centre for Financial Research (CFR).

Niessen-Ruenzi, A., \& Ruenzi, S. (2013). Sex matters: Gender and prejudice in the mutual fund industry. Retrieved from https://ssrn.com/abstract=1957317. https:// doi.org/10.2139/ssrn.1957317 
Pasban, M., \& Nojedeh, S. H. (2016). A review of the role of human capital in the organization. Procedia - Social and Behavioral Sciences, 230, 249-253. https:// doi.org/10.1016/j.sbspro.2016.09.032

Shukla, R., \& Singh, S. (1994). Are CFA charterholders better equity fund managers? Financial Analysts Journal, 50(6), 68-74. https://doi.org/10.2469/faj.v50.n6.68

de Souza, A. (2013). A mispricing-based explanation of how flow affects mutual fund performance (Research Paper, No. 2326030). New York: Fordham University Schools of Business. https://doi.org/10.2139/ssrn.2326030

Switzer L. N., \& Huang Y. (2007). How does human capital affect the performance of small and mid-cap mutual funds? Journal of Intellectual Capital, 8(4), 666-681. https://doi.org/10.1108/14691930710830828

Tan, E. K. M., \& Sen, A. (2019). Does educational diversity of managers matter for the performance of team-managed funds? Accounting and Finance, 59, 801-830. https://doi.org/10.1111/acfi.12265

Welch, S., \& Wang, Y. (2013). Is manager gender important in the performance of mutual funds. Accounting and Finance Faculty Publications, 6, 1-31.

Zaremba, A., Czapkiewicz, A., Szczygielski, J., \& Kaganov, V. (2019). An application of factor pricing models to the Polish stock market. Emerging Markets Finance and Trade, 55(9), 2039-2056. https://doi.org/10.1080/1540496X.2018.1517042

Zaremba, A. (2018). Downloadable data. Retrieved from http://adamzaremba.pl/ downloadable-data/ 